\title{
GORRIGENDUM
}

\section{From Host Country Nationals to Entrepreneurs: Insights from Professional Service Ventures in Vietnam - Corrigendum}

\section{Yen Tran, Snejina Michailova, and Huong Nguyen}

DOI: https://doi.org/10.1017/mor.2021.27; first published online by Cambridge University Press 27 August 2021

In the initial publication of Tran et al. (2021), the affiliation for co-author Huong Nguyen was printed incorrectly. The original publication has since been updated to include Nguyen's correct affiliation.

\section{Reference}

Trans, Y., Michailova S. Nguyen H. From Host Country Nationals to Entrepreneurs: Insights from Professional Service Ventures in Vietnam. Management and Organization Review, first published online 27 August 2021. doi:10.1017/mor.2021.27. 